\title{
The Influence of Pandemics on Students' Online Activities
}

\author{
Irina Maiorescu ${ }^{1}$, Mihaela Bucur ${ }^{2}$, Daniel Moise ${ }^{3}$ and Bogdan Georgescu ${ }^{4}$ \\ 1) 2)3) The Bucharest University of Economic Studies, Bucharest, Romania. \\ E-mail: irina.maiorescu@com.ase.ro; E-mail: mihaela.bucur@com.ase.ro; \\ E-mail: moisedaniel@gmail.com; E-mail: bogdan.georgescu@mk.ase.ro
}

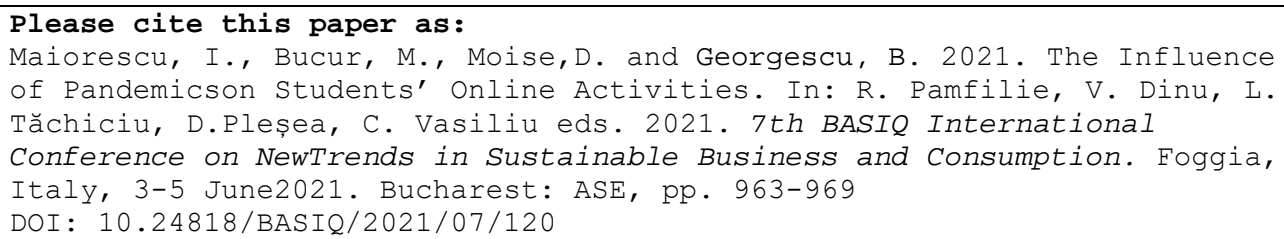

\begin{abstract}
The 2020 - 2021 COVID-19 pandemics shifted the educational and social behavioral patterns of mankind, because of the safety regulation taken by authorities across the globe. People and businesses had to rethink their activities, the online environment being the main support for social, business and academic communication. The current paper aims to analyze the way higher education students changed their behavior about online activities, during pandemics. As such, an online quantitative research was deployed at the end of May 2020, after 2 months of national lockdown and severe restrictions of social face-to-face interaction, on 193 students from Bucharest University of Economic Studies. The results indicate that the pandemics generated increased online activities, in general. In particular, it was found that the gender of respondents and the year of study are associated with the increased amount of time spent for certain online activities, such as getting informed for a potential future business, online shopping and getting informed to be prepared for university courses and projects. The research contributes to a better understanding of students' online behavioral patterns in a prolonged global lockdown situation generated by pandemics and offers useful insights for potential future changes in higher education based on online activities.
\end{abstract}

\section{Keywords}

Online environment, pandemics, COVID 19, behavior, higher education, students, gender DOI: $10.24818 / B A S I Q / 2021 / 07 / 120$

\section{Introduction}

Information and communication technologies develop at an incredible fast pace and people - especially younger generations, depend more and more on using these, in every aspect of their living (Ogan, Ozakca and Groshek, 2008; Cai, Fan and Du, 2017). The spectacular growth of e-commerce (Chaffey, 2021), of online learning (Koksal, 2020) and social media (Tankovska, 2021) shows the extent of immersion in the virtual environment our society has. However, studies show that too much spending time online on computers, or mobile devices, leads to health and social issues on the long run, especially with young people (Nalwa and Anand, 2003; Twenge, 2013; Jiang, 2014).

COVID 19 pandemics generated states of emergency and states of alert in most of the countries, with severe restrictions of social interaction and travelling. Many areas of activity were affected by these measures, the education sector making no exception from it here. On campus activities were suspended - aiming at reducing social interaction and, hence, disease spreading (Bakshi, et al., 2021). Learning and education were suddenly transferred in the online environment and children, teenagers and young people were thus forced to spend their usual on campus learning time in front of computers, or other mobile devices connected to internet. 
The current paper analyzes the way higher education students changed their behavior in online environment during pandemics in terms of time spent and activities performed online. It starts from an analysis of the scientific literature about online activities of students and the effects the pandemics has brought upon society and education, which is presented in the first section. Our paper continues next with discussing the design and results of the quantitative research we deployed at the end of Romanian national emergency state in May 2020, with the purpose of identifying the impact of pandemics on students online activities. Conclusions with future directions of research are presented in the last part of the paper, which contributes thus to deepening the understanding of pandemics lockdown effects on human behavior.

\section{Review of the scientific literature}

In the beginning of 2020, the World Health Organization (WHO) declared COVID-19 a health emergency (WHO, 2020). As a results of virus spread, countries across the globe introduced lockdown measures, trying to minimize social interactions and to reduce group exposure. In this context, schools and universities had to rapidly move their courses in the online environment, billions of students experiencing these sudden changes (Sukendro. et al., 2020). Academic staff and students quickly had to adapt to the specificity of online learning, without any previous special preparation (AguileraHermida. et al, 2021).

The online environment provides rapid and easy access to information; hence this unexpected shift to e-learning might not be considered a problem. However, leaving aside the issue of infrastructure, which requires that students belonging to poor families have access to technology, in order to attend the online classes, there is a question about the health consequences of prolonged staying in front of a screen for young people (House of Commons, 2019).

Even before pandemics, students spent much time online, but the lockdown forced students to spend their on-campus time in front of a screen. For instance, the percent of Polish students who spent over six hours on online activities daily, during weekdays, increased by $42 \%$ compared to the time before pandemics (Wanat, 2021). In Romania, there were reported between four and eight hours of online staying, during the emergency lockdown. At the same time, nearly one out of ten people was spending up to 12 hours on the internet(Sava, 2021). Taking into consideration the social isolation and the uncertainties of the future, it is only natural that students should want to be connected to their social circles and to the latest news.

While being online, students spend indeed a certain time for learning, for solving tasks and making projects; however, social media, online leisure times (gaming, listening to music, streaming, video watching etc), business/work activities increase the time students stay connected to the internet (Educase, 2021). As a matter of fact, a study on British students revealed that, out of the average of 55 hours spent online in a week, only 14 hours were dedicated to university work (Hughes, 2019).

Among various online activities, social media is one of the most popular, the Social Media Generation expecting "instantaneous communication and feedback, engaging content, and accessibility" (Reid and Prudchenko, 2014). While studies report that there are differences in the online behavior of people (Seock and Bailey, 2008; Ye, et al., 2018), according to their gender, their results may be contradictory. Thus, and Jones, et al. (2009), point to the fact that female students spend more time communicating online, while a study of Alnjadat, et al. (2019) reveals that male respondents were more addicted to Social Media than female respondents. Regardless of these, it has come to a common opinion that people, especially young ones, spend too much time online, in various activities.

\section{Research methodology}

Starting from the issues identified through the analysis of the scientific literature, we conducted a quantitative research aimed at analyzing the way pandemics lockdown in Romania, during March May 2020, influenced the online behavior of students, in terms of time spent on various activities.

We considered that it was important that students had at least one year of normal on campus academic activity, in order to be able to compare their online behaviors - among which university related ones, 
during pandemics versus before pandemics. Consequently, we aimed at investigating students enrolled in the $2^{\text {nd }}$ and $3^{\text {rd }}$ year of bachelor studies, as well as those enrolled in the master programs.

The quantitative research was based on an online questionnaire, designed on Google Docs platform, distributed in May 2020, just at the end of the national state of emergency, to 268 students belonging to Marketing Faculty and Business and Tourism Faculty from Bucharest University of Economic Studies. The sampling was non-probabilistic, with a total of 193 complete and valid questionnaire responses. There were 123 female and 70 male respondents, 92 of them being bachelor students enrolled in the $2^{\text {nd }}$ and $3^{\text {rd }}$ year and 101 being master students.

Data retrieved from Google Docs platform hosting our questionnaire composed of 19 questions were first processed with Microsoft Excel and then analyzed with the statistical software Minitab 16.

\section{Results and discussion}

Our analysis focused first on assessing the time students spent online during lockdown, as compared to before lockdown, when they had to go on campus for attending their courses and seminaries. The results presented in Figure no.1, indicate that almost $80 \%$ of students declare they spend more time online than they did before pandemics.

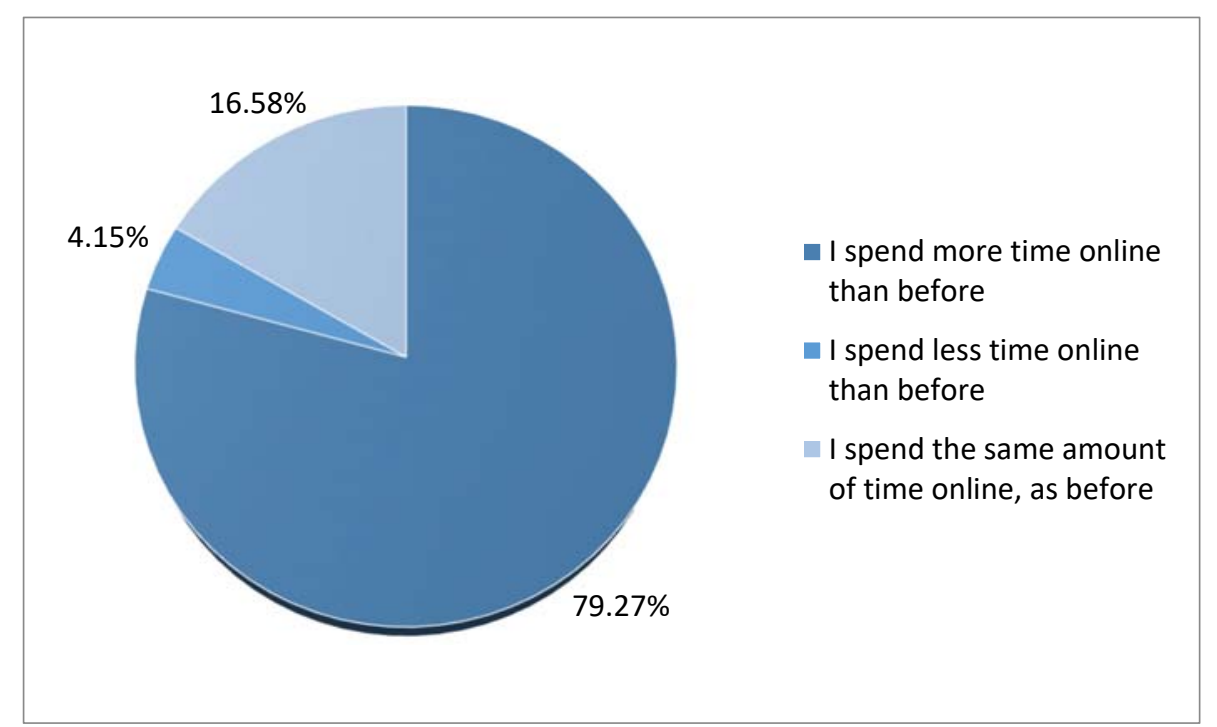

Figure no.1. The distribution of answers regarding online time spent during pandemics versus before pandemics

Given the fact that studies generally suggest that students even in a normal life, without social interaction restrictions, spend more time in front of the computer, than it would be healthy for their physical and mental wellbeing, these results raise worrying questions about the overall benefic effects of on campus studying ban.

Next, respondents were asked to point out those online activities where they spent more time during pandemics lockdown, than before. We listed various types of activities, ranging from Social Media where we included two of the most popular ones for social purposes - Facebook and Instagram (Tankovska, 2021), and for professional networking - Linked In, online shopping, hobbies and leisure activities and looking for future business opportunities. The results are presented in Table no.1. 
Table no. 1. Online activities where respondents spent more time than before pandemics

\begin{tabular}{|c|c|}
\hline Online activities & $\%$ of respondents \\
\hline Instagram & $72,02 \%$ \\
\hline Online shopping & $63,21 \%$ \\
\hline Information for school courses and projects & $60,10 \%$ \\
\hline News & $53,89 \%$ \\
\hline Information about hobbies, leisure activities & $53,37 \%$ \\
\hline Facebook & $48,19 \%$ \\
\hline Information for a potential business & $27,46 \%$ \\
\hline LinkedIn & $7,77 \%$ \\
\hline Other activities - business related & $1,04 \%$ \\
\hline
\end{tabular}

An interesting fact to remark is that students did not use their time at home more than usual to prepare their future business careers, but they rather looked more for the "normality" they lacked: variation of images and news about the world. Online shopping activity can be explained by the fact that the restrictions made quite difficult the physical shopping process of various articles which were not considered by authorities as vital; hence, this high number of more active than before online shoppers.

Next we were interested in identifying whether there is an association between the various online activities, where respondents declared that they had spent more time than before pandemics, and gender, respectively year of study. Pearson Chi Square test of association was performed, its results being presented in table no. 2 .

Table no.2. Pearson Chi Square Test of association between variables "online activities" and "gender", respectively "year of study"

\begin{tabular}{|c|c|c|}
\hline \multirow{2}{*}{ Online activities } & \multicolumn{2}{|c|}{ Cross Tabulation with: } \\
\hline & Gender & Year of study \\
\hline Online shopping & $\begin{array}{l}\text { Pearson Chi-Square = 3.764; } \\
\quad D F=1 ; P \text {-Value }=0.052^{*}\end{array}$ & $\begin{array}{c}\text { Pearson Chi-Square }=0.975 \\
\mathrm{DF}=2 ; \mathrm{P}-\text { Value }=0.614\end{array}$ \\
\hline Facebook & $\begin{array}{c}\text { Pearson Chi-Square }=0.048 \\
\mathrm{DF}=1 ; \mathrm{P}-\text { Value }=0.827\end{array}$ & $\begin{array}{c}\text { Pearson Chi-Square }=2.713 ; \\
\mathrm{DF}=2 ; \mathrm{P}-\text { Value }=0.258\end{array}$ \\
\hline LinkedIn & $\begin{array}{l}\text { Pearson Chi-Square }=0.649 \\
\mathrm{DF}=1 ; \mathrm{P} \text {-Value }=0.421\end{array}$ & $\begin{array}{c}\text { Pearson Chi-Square }=4.999 ; \\
\mathrm{DF}=2 ; \mathrm{P}-\text { Value }=0.082\end{array}$ \\
\hline News & $\begin{array}{l}\text { Pearson Chi-Square }=2.010 \\
\mathrm{DF}=1 ; \mathrm{P}-\text { Value }=0.156\end{array}$ & $\begin{array}{c}\text { Pearson Chi-Square }=1.256 ; \\
\mathrm{DF}=2 ; \mathrm{P}-\text { Value }=0.534\end{array}$ \\
\hline Instagram & $\begin{array}{l}\text { Pearson Chi-Square }=3.261 \\
\text { DF }=1 ; \text { P-Value }=0.071\end{array}$ & $\begin{array}{c}\text { Pearson Chi-Square }=3.022 ; \\
\mathrm{DF}=2 ; \mathrm{P}-\text { Value }=0.221\end{array}$ \\
\hline $\begin{array}{l}\text { Information for university courses and } \\
\text { projects }\end{array}$ & $\begin{array}{l}\text { Pearson Chi-Square }=3.447 \\
\mathrm{DF}=1 ; \mathrm{P}-\text { Value }=0.063\end{array}$ & $\begin{array}{c}\text { Pearson Chi-Square }= \\
\text { 9.998; DF }=2 ; P-\text { Value }= \\
0.007^{*}\end{array}$ \\
\hline Information for a potential future business & $\begin{array}{c}\text { Pearson Chi-Square }=8.669 ; \\
D F=1 ; \text { P-Value }=0.003^{*}\end{array}$ & $\begin{array}{c}\text { Pearson Chi-Square }=4.692 ; \\
\mathrm{DF}=2 ; \mathrm{P}-\text { Value }=0.096\end{array}$ \\
\hline $\begin{array}{c}\text { Information about hobbies/leisure } \\
\text { activities }\end{array}$ & $\begin{array}{l}\text { Pearson Chi-Square }=0.145 \\
\mathrm{DF}=1 ; \mathrm{P}-\text { Value }=0.704\end{array}$ & $\begin{array}{c}\text { Pearson Chi-Square }=1.089 ; \\
\mathrm{DF}=2 ; \mathrm{P}-\text { Value }=0.580\end{array}$ \\
\hline
\end{tabular}

*significance level for p-value: 0.05 
As it can be seen in table no. 2 there is an association between the year of study and spending more time to get informed for university projects and courses, $p$-value being of 0.007 . The distribution of answers indicates that bachelor students from the $2^{\text {nd }}$ and $3^{\text {rd }}$ year of study spent more time than before pandemics for getting informed for courses and projects, as compared to master programs students. This result does not necessarily imply that master students were not as serious during lockdown as bachelor students; it rather shows that master students, who are almost all employed and are attending tiring courses at the end of their work program, look for additional online information in order to keep up with courses requirements, before and after pandemics.

Also, it can be noticed, right above the cut off value ( $p$-value is 0.052 ), that there is an association between spending more time for online shopping and gender (see table no.2). The analysis of answers distribution shows that female respondents stated in a higher proportion than male respondents that they had spent more time for online shopping in pandemics than before.

Another association was revealed, between gender and the preoccupation for getting informed for a potential business ( $\mathrm{p}$-value is 0.003 ). The cross tabulation between these variables indicates that male respondents declared in a higher proportion than female respondents an increased spending of time to get informed about opportunities for a potential business.

There were found no other associations between the other online activities and gender, respectively year of study.

\section{Conclusions}

The restrictions generated by the pandemics from 2020-2021 resulted in disruptions of the social and educational patterns of students. The immediate result of the emergency lockdown which took place in Romania, as well as in many countries across globe, at the beginning of pandemics, was a massive shift of the social and educational activities in the online environment.

Even before pandemics, there were concerns about the time young people spend in front of computers or mobile devices, connected online for various activities. Social isolation and online education, during this period, are premises for even more increased times spent online and for generating addictive habits and health issues. As such, the current paper, aimed to investigate the new patterns of online behavior in higher education students, as induced by the pandemics lockdown.

The results of the quantitative research deployed at the end of lockdown period, confirmed other research in the area, stating that students have increased their time spent online during lockdown. Social media and news were activities where students spent more time than before pandemics; on the other hand, career(Linked In) and prospecting information for potential businesses were hardly given more time than before pandemics. There was found an association between gender and getting informed about potential businesses, meaning that a higher percentage of male students spent more time in pandemics, than before it, higher percentage than female respondents prospecting for a future business. Also, a higher percentage of female respondents spent more time for online shopping, as compared to male respondents.

The research has limitations induced by sample specificity. Nontheless, its results confirm the influence of pandemics on students'online activities, the purpose of our paper. A further direction of research will consist in measuring the change of students'online behavior along pandemics stages, as well as after its ending. It is important to assess in time the effects of such a major event, so that better social and educational policies could be issued, in case of facing similar future challenges.

\section{References}

Aguilera-Hermida, A.P., Quiroga-Garza. A., Gómez-Mendoza, S., Del Río Villanueva, C.A, Avolio Alecchi, B. and Avci, D., 2021. Comparison of students' use and acceptance of emergency online learning due to COVID-19 in the USA, Mexico, Peru, and Turkey. Educ Inf Technol (Dordr), 14, pp.1-23. 
Alnjadat, R., Hmaidi, M.M., Samha, T.E., Kilani, M.M. and Hasswan, A.M., 2019. Gender variations in social media usage and academic performance among the students of University of Sharjah. Journal of Taibah University Medical Sciences, 14(4), pp. 390-394.

Bakshi, S., Wasim, A., Truong, J. and Majid, U., 2021. Attitudes, Perceptions of Risk, and Behavior Change of Students During Pandemics: A Systematic Review. ResearchSquare, [online] Available at: <https://europepmc.org/article/ppr/ppr261150> [Accessed 11 March 2021].

Cai, Z., Fan, X. and Du, J., 2017. Gender and attitudes toward technology use: A meta-analysis. Computers \& Education, 105, pp.1-13.

Chaffey, D., 2021. Forecast e-commerce growth in percentage of online retail / e-commerce sales 2017 to 2023, Smart Insights, [online]. Available at: < https://www.smartinsights.com/digital-marketingstrategy/online-retail-sales-growth/> [Accessed 18 April 2021].

Educase, 2021. A Day in the Online Life of a Student, [online] Available at: $<$ https:/www.educause.edu/ecar/research-publications/ecar-study-of-undergraduate-students-andinformation-technology/2018/a-day-in-the-online-life-of-a-student> [Accessed 10 April 2021].

House of Commons, 2019. Impact of social media and screen-use on young people's health. Fourteenth Report of Session 2017-19. [pdf] Available at: $<$ https://publications.parliament.uk/pa/cm201719/cmselect/cmsctech/822/822.pdf $>$ [Accessed 10 April 2021].

Hughes, A., 2019. British students use one-quarter of their time online for studying, poll claims. Independent, [online] Available at: <https://www.independent.co.uk/news/education/educationnews/university-students-internet-studying-uk-social-media-survey-a9111531.html $>$ [Accessed 11 April 2021].

Jiang, Q., 2014. Internet addiction among young people in China: Internet connectedness, online gaming, and academic performance decrement. Internet Research, 24(1), pp.2-20.

Jones, S., Johnson-Yale, C., Millermaier, S. and Pérez, F.S., 2009. U.S. College Students' Internet Use: Race, Gender and Digital Divides. Journal of Computer-Mediated Communication, 14(2), pp.244264.

Koksal, I., 2020. The Rise of Online Learning. Forbes, [online]. Available at: $<$ https://www.forbes.com/sites/ilkerkoksal/2020/05/02/the-rise-of-online-learning/?sh=1415ff6472f3 $>$ [Accessed 19 April 2021].

Nalwa, K. and Anand, A.P., 2003. Internet addiction in students: a cause of concern. Cyberpsychology \& behavior: the impact of the Internet, multimedia and virtual reality on behavior and society, 6(6), pp.653-656.

Ogan, C.L., Ozakca, M. and Groshek, J., 2008. Embedding the internet in the lives of college students: Online and offline behavior. Social Science Computer Review, 26(2), pp.170-177.

Reid, A.J. and Prudchenko, K., 2014. Online behavior of the social media student. In: Digital arts and entertainment: Concepts, methodologies, tools, and applications. IGI Global, pp.1032-1047.

Sava, J.A., 2021. Time spent online during the emergency regime in Romania 2020. Statista, [online] Available at: <https:/www.statista.com/statistics/1194712/romania-time-spent-online-duringcovid-19/\#statisticContainer> [Accessed 18 April 2021].

Seock, Y.K. and Bailey, L.R., 2008. The influence of college students' shopping orientations and gender differences on online information searches and purchase behaviours. International Journal of Consumer Studies, 32(2), pp.113-121.

Sukendro, S., Habibi, A., Khaeruddin, K., Indrayana, B., Syahruddin, S., Makadada, F. A. and Hakim, H., 2020. Using an extended Technology Acceptance Model to understand students' use of e-learning during Covid-19: Indonesian sport science education context. Heliyon, 6(11), Article number: e05410. 
Tankovska, H., 2021. Number of global social network users 2017-2025. Statista, [online] Available at: <https://www.statista.com/statistics/278414/number-of-worldwide-social-network-users/> [Accessed 18 April 2021].

Twenge, J.M., 2013. Does Online Social Media Lead to Social Connection or Social Disconnection? Journal of College and Character, 14(1), pp.11-20.

Wanat, G., 2021. Week days time spent online by Polish students before and after school closures 2020. Statista, [online] Available at: <https:/www.statista.com/statistics/1223919/poland-week-daystime-spent-online-by-students-before-and-after-school-closures/\#statisticContainer $>$ [Accessed 11 April 2021].

WHO, 2020. Novel Coronavirus (2019-nCoV) Situation Report-11, [online] Available at: $<$ https://www.who.int/docs/default-source/coronaviruse/situation-reports/20200131-sitrep-11ncov.pdf?sfvrsn=de7c0f7_4> [Accessed 22 April 2021].

Ye, Z., Hashim, N.H., Baghirov, F. and Murphy, J., 2018. Gender differences in Instagram hashtag use. Journal of Hospitality Marketing \& Management, 27(4), pp.386-404. 